\title{
Parcerias intraeuropeias: 50 anos do Tratado do Eliseu (1963-2013)
}

\author{
Intra-European partnership: \\ the 50 years of the Elysée Treaty (1963-2013)
}

ESTEVÃO C. DE REZENDE MARTINS*

Rev. Bras. Polít. Int. 56 (1): 60-84 [2013]

Em 22 de janeiro de 2013 a Alemanha e a França celebram os cinquenta anos do Tratado de Cooperação Franco-Alemã, conhecido como o Tratado do Eliseu, de 1963. Esse tratado marca inicialmente uma inédita parceria francoalemã, que passou desde os anos 1960 por incontáveis altos e baixos. Sem esse marco da política internacional, contudo, inúmeros obstáculos para a integração europeia e para a política externa convergente não teriam sido superados. É certo que algumas determinantes da época hoje já não mais existem, como a ameaça do comunismo e a pressão da Guerra Fria. Outras surgiram, como as sucessivas ondas de terrorismo internacional, notadamente após o 11 de setembro de 2001. Cabe lembrar, contudo, nem que seja de passagem, que as crises anteriores de terrorismo interno (Irlanda, Itália, Espanha e Alemanha, sobretudo) também contribuíram para a consolidação dessa primeira parceria estratégica na Europa.

Trata-se certamente de mais uma das histórias de sucesso do itinerário da União Europeia, uma "boa entente", como afirmou o terceiro presidente da 5a República Francesa, Valéry Giscard d'Estaing (1974-1981). No entanto, com o alargamento da União e com a complexidade crescente do mundo contemporâneo, essa parceria não se teria um tanto diluído? O surgimento de outras ambiçóes de liderança, com efeito, tornaram os processos decisórios mais difíceis e as rivalidades políticas mais agudas. Com isso, a política interna, como a externa, vem se europeizando gradual e regularmente. Diversos temas originalmente de política "externa" tornaram-se praticamente de política interna. O Tratado do Eliseu se insere nessa lógica. No plano internacional - França e Alemanha são Estados soberanos e autônomos -, é um tratado clássico. No plano europeu, dá um passo significativo no caminho da transposição de elementos internacionais para o campo interno. Pode-se ver nessa transposição alguma ambiguidade, na medida em que

* Professor titular de História da Universidade de Brasília (UnB) e pesquisador do Conselho Nacional de Desenvolvimento Científico e Tecnológico (CNPq) (echarema@gmail.com). 
os Estados não desapareceram, até o presente, embora haja um processo contínuo e crescente de transferências de soberania para as instituições federais europeias.

Um fato preponderante para o funcionamento da dupla França-Alemanha está na igualmente dupla dependência entre os parceiros e deles para com a União Europeia. Pode-se considerar esse formato de política interna e externa de bilateralismo complementar. As crises mais recentes e as dúvidas sobre a eficácia da liderança da dupla franco-alemã em tempos mudados levam a se perguntar se as consultas regulares entre Paris e Berlim, tão importantes até o final dos anos 1990, não teriam perdido algo de sua força. Durante longos anos essa cooperação pareceu ser a força motriz da preservação do acquis communautaire e propulsora de seus avanços, como no caso do Ato Europeu Único, de $1986 .{ }^{1}$

Para a conformação atual da política externa europeia, essa parceria continua a possuir uma notável relevância histórica. A presente reflexão esboça a origem do tratado, sua importância para a parceira franco-alemã e para a evolução da política da União, e conclui com uma análise dos desdobramentos possíveis na atual quadra.

\section{Origem do tratado}

Logo após o término da 2a Guerra Mundial, um tratado de amizade francoalemão era impensável. Dezoito anos depois, com a França presidida por um dos principais líderes da vitória na guerra e na derrota do nazismo, Charles de Gaulle, e a Alemanha governada por um de seus primeiros resistentes, o ex-prefeito de Colônia, Konrad Adenauer, mentalidades, políticas e decisōes haviam tomado uma direção radicalmente nova e inovadora, para ambas as partes. Quase duas décadas de políticas perseverantes de reconciliação e de entendimento recíproco entre os dois países - e as duas sociedades - explicam-se em boa parte pela convergência política acerca de um futuro comum no âmbito de uma Europa integrada. Com eles, mas também para além deles. A paz e o afastamento do risco de outros conflitos, em que as ameaças se haviam deslocado para fora da França e da Alemanha, exigiam a superação das tensões entre os dois países, que haviam chegado a ser estigmatizadas como uma "inimizade hereditária”.

O entendimento franco-alemão não é apenas uma política de belos gestos simbólicos, mas um meio longamente eficaz de realização pacífica de interesses compartilhados. Um dos motivos para a disposição de ambos os países de vincularse, no longo prazo, por um tratado, foi o temor mútuo das eventuais consequências negativas de uma política nacional, isolada, com relação ao leste europeu. Paris receava que a República Federal, apesar dos vínculos com as alianças ocidentais,

1 Um excelente balanço das posições positivas (força motriz) e das posiçôes negativas (força de bloqueio) pode ser lido em Siedentopf, Heinrich; Speer, Benedikt (orgs.). Deutschland und Frankreich in der europäischen Integration: 'Motor' oder 'Blockierer?' / L'Allemagne et la France dans l'intégration européenne: 'moteur' ou 'frein'? Berlim: Duncker \& Humblot, 2011. O balanço conclui pela exemplaridade e incontornabilidade da parceria franco-alemã no processo europeu, ad intra e ad extra. 
pudesse vir a ser aspirada pela União Soviética. Bonn temia que uma política francesa de apaziguamento e convivência a leste se fizesse às custas da Alemanha.

Os dois países recusaram sem hesitação a nota de Estaline, de março de 1952, com a proposta de uma Alemanha reunificada, mas neutra. As razões para tal recusa foram diversas, em termos de política nacional, mesmo se o resultado foi o mesmo. A França considerou com elevada desconfiança uma "neutralidade" tutelada pela União Soviética. A experiência com outros países do leste europeu não preconizava nada de bom. A República Federal não concebia outro formato de reunificação que não fosse o da opção pelo Ocidente e por sua arquitetura de aliança defensiva - a Organização do Tratado do Atlântico Norte (Otan). A fórmula do discurso de Robert Schuman em 9 de maio de 1950 prevaleceu, tanto para a opção política interna quanto externa. Criar, manter e desenvolver as comunidades europeias tornou-se, com grande rapidez, um objetivo estratégico maior.

Havia também outros motivos e razões para uma cooperação estreita dos dois países em políticas comuns. A França, com a intenção de recuperar sua autoestima de "grande nation" e sua agência na política internacional, tinha também interesse em aproximar de si a República Federal da Alemanha, evitando que ela ficasse exclusivamente sob a influência estadunidense. A liderança dos americanos com relação à Alemanha e à Europa em geral sempre foi uma pedra no sapato de Paris, pois conflitava com seus interesses nacionais e europeus. Bonn esperava lograr, com uma cooperação estreita, consolidar e aprofundar o vínculo, bem sucedido, com as estruturas ocidentais, de modo a ser incluído no "clube" dos parceiros políticos internacionais confiáveis. Ademais, Bonn buscava amenizar a atitude antiamericana dos franceses, de modo a preservar o quanto possível um entendimento eficiente no interior da Otan. Nesse contexto, a Alemanha dependia de uma boa parceria tanto com a França quanto com os Estados Unidos. Assim, a habilidade política de não se tornar um joguete das pretensões de poder de ambos os países foi um requisito essencial da ação alemã nos anos 1950 e 1960.

A assinatura do Tratado do Eliseu em 1963 foi o ápice da hábil política de entendimento do chanceler federal Konrad Adenauer, praticada desde o dia seguinte do armistício que selou a derrota da Alemanha nazista, em maio de 1945. Alguns engajamentos fundantes a precederam. O Plano Schuman, de 1950, que criou a Comunidade Europeia do Carvão e do Aço (CECA), a primeira instituição supranacional na Europa, foi um marco decisivo. Sete anos após o fim da guerra e somente três anos depois da formalização da República Federal, a Alemanha ingressava de pleno direito no círculo dos vizinhos europeus ocidentais. Um passo decisivo para a reconciliação franco-alemã. Em $1^{\circ}$ de janeiro de 1958 entram em vigor os tratados da Comunidade Econômica Europeia (CEE) e da Comunidade Europeia do Átomo (Euratom). Economia e energia são mais duas políticas públicas da Europa dos Seis que passam do plano estritamente interno ("nacional") para o comum ("externo"). Uma terceira política pública - a de defesa - tropeça na recusa da Assembleia Nacional francesa, em 1954, de ratificar a Comunidade Europeia 
de Defesa. A política de segurança (e dos arsenais de defesa, sobretudo em meio à corrida nuclear), em tempos de Guerra Fria, e para a França, refém de persistentes guerras coloniais (Indochina e, logo, Argélia), ainda era demasiado sensível.

Com o rápido engajamento multilateral da Alemanha no espaço europeu e ocidental, é de se perguntar por que um bilateralismo franco-alemão seria ainda necessário. Um elemento de resposta está no fato de que a união propriamente política dos seis estados-membros das Comunidades ainda não se realizara. Os desequilíbrios políticos dessa época começam a poder ser superados após a queda do Muro de Berlim, em 1990, embora outros desequilíbrios se tenham introduzido no espaço europeu, pela expansão acelerada no final dessa década.

Nos anos 1960, Paris e Bonn entenderam que ainda se fazia necessário aparar arestas, acertar ponteiros, coordenar políticas, mesmo se isso não representasse uma fusão direta de objetivos e meios. Paris sabia que a recém-criada Alemanha Federal dependia de uma política externa fundada na confiança e trabalhava com a hipótese de que Bonn poderia ser uma espécie de seu parceiro acessório na realização dos interesses próprios franceses na Europa. Essa hipótese era de certa maneira otimista, na medida em que Bonn - mesmo se prudente e cuidadosa nas políticas europeia e internacional - via com ceticismo o antiamericanismo francês e considerava que uma cooperação intensificada permitiria à Alemanha amenizar tal política. Ambas as partes julgavam, no entanto, como estrategicamente incontornável um tratado que firmasse o caminho da cooperação pacífica entre elas como requisito para avanços no espaço europeu e avanços da Europa na cena mundial.

Apesar do ambiente de uma crescente aproximação, a decisão propriamente dita de celebrar formalmente o tratado foi tomada em prazo brevíssimo. $\mathrm{O}$ chanceler federal Adenauer pensava inicialmente em um acordo reservado. Em 1962, diversas crises sacudiram a cena internacional e a política interna alemã. Desde a construção do muro de Berlim, Adenauer vinha sendo exposto a sinais preocupantes de desgaste da liderança que exercia desde o fim da 2a Guerra. A bancada democrata-cristã do governo, no Parlamento Federal, travou um forte debate que opôs "gaullistas" e "atlantistas", a propósito da crise dos mísseis de Cuba, evidenciando a perda de coesão quanto à política externa. Ademais, a crise decorrente da acusação governamental de traição contra o semanário Der Spiegel, em outubro desse ano, por motivo de um artigo sobre a incapacidade de defesa da Alemanha no caso de ataque pelo Pacto de Varsóvia, quase levou à dissolução da coligação governamental e acarretou a queda do ministro da Defesa, Franz-Josef Strauss, pivô da crise. A percepção de Adenauer de que seu governo estaria correndo o risco de terminar afinal veio a ser confirmada (cerca de um ano mais tarde Adenauer se retira). Assim, o chanceler acelera o movimento político internacional, a começar pelo tratado com a França.

Firma-se assim o bilateralismo franco-alemão como peça-chave da política europeia, que de certa maneira contornava a ideia de Charles de Gaulle de somente apoiar uma "Europa das pátrias", frase sibilina lançada pelo presidente francês 
em entrevista em 15 de maio de 1962, manifestando sua resistência à crescente tendência europeizante das políticas, notadamente da externa. Adenauer tencionava também deixar para seus sucessores uma plataforma de íntima vinculação com a França, imune o quanto possível às eventuais incertezas futuras na política de seu país ou das grandes potências, cujo risco de confronto era percebido como agudo. O bilateralismo franco-alemão era também uma alternativa europeia plausível ao sobrepeso transatlântico dos Estados Unidos e a seu posto avançado na Europa: a Grã-Bretanha.

A minuta do tratado foi redigida e negociada em tempo recorde e assinada solenemente na sede da presidência francesa, o Palácio do Eliseu, em Paris, em 22 de janeiro de 1963. O Tratado do Eliseu é, indiscutivelmente, a obra-prima de política europeia e internacional de Adenauer: no âmbito da política externa multilateral da Alemanha Federal, a dupla franco-alemã representa um pilar original, cuja peculiaridade o coloca fora e acima da categoria clássica dos tratados bilaterais. ${ }^{2}$

A celebração do tratado se dá no mesmo momento em que de Gaulle se opõe tenazmente a que as Comunidades Europeias admitam a Grã-Bretanha. A dupla Paris-Bonn é assim objeto de críticas tanto pela oposição social-democrata alemã quanto pelo governo estadunidense de John F. Kennedy. Ambos receavam que a Alemanha se filiasse à política externa francesa de resistência aos ingleses, o que colocaria em risco a coesão da aliança da Otan e poderia ensejar o isolamento da Grã-Bretanha.

O sucesso do tratado de 1963 não deixa margem a dúvida, mas a classe política alemã sentiu o ambiente indeciso dos parceiros atlânticos, notadamente os Estados Unidos - a cuja política e a cujo apoio se devia substancial parte do soerguimento alemão. Jean Monnet, federalista europeu de profunda conviç̧ão (e nisso em oposição a de Gaulle), queria a todo preço evitar tal risco de afastamento da aliança atlântica e logrou ser escutado no Parlamento Federal alemão. Com efeito, a lei alemã de ratificação do tratado, em maio de 1963, antepôs-lhe um preâmbulo, no qual se reafirma o engajamento da Alemanha Federal nas estreitas relaçôes de cooperação política, econômica e de defesa com os Estados Unidos, com a Grã-Bretanha e com a Otan, bem assim o engajamento com o objetivo vital da reunificação alemã. Essa providência estabeleceu uma forma de equilíbrio entre atlantistas e francófilos na política externa alemã e sinalizou a recusa da Alemanha de um novo tipo de isolamento (o de uma Europa que voltasse às costas a seu principal avalista, os Estados Unidos). Obviamente de Gaulle, embora não o pudesse evitar, deixou entrever seu desagrado por não conseguir manter intocado seu "grande desígnio" para a liderança francesa. ${ }^{3}$

2 Adolf Kimmel/Pierre Jardin (orgs.). Die deutsch-französischen Beziehungen seit 1963. Eine Dokumentation (Frankreich-Studien, vol. 6). Opladen: Leske + Budrich, 2002.

3 A França domina a tecnologia nuclear ofensiva desde 1960. A "força de dissuasão", eufemismo de caráter defensivo, constitui um trunfo estratégico que nutre a sensação de "potência restabelecida" do governo francês. 


\section{Institucionalização das relações bilaterais}

Logo após a formalização do Tratado do Eliseu, as relações entre França e Alemanha não passaram por nenhuma mudança notável: a amizade de fundo não suprimiu as diferenças na análise de conjuntura. Além da questão atlântica, as percepçôes dos dois governos também divergiam quanto à ameaça soviética. A França olhava a União Soviética com certa mansidão autossuficiente e intelectualizada. Em sua política interna, um partido comunista forte (com cerca de $20 \%$ do eleitorado nas décadas de 1960 e 1970) hipotecava - negativamente, é certo - o modus operandi da política externa francesa quanto ao bloco soviético. A Alemanha Federal via no bloco soviético uma espada de Dâmocles ameaçadora sobre sua nuca política, territorial e econômica. A fratura de 1945, acentuada com o muro de 1961, nada lhe fazia pressagiar de bom para o horizonte alemão. Essa percepção será alterada somente a partir de 1972, com o advento da Ostpolitik do chanceler social-democrata Willy Brandt, que rompe pela primeira vez os constrangimentos ideológicos internacionais que mantinham atada a Alemanha Federal. ${ }^{4}$ No entanto, os mecanismos de consulta e de coordenação política, administrativa e econômica se instalam e as "cimeiras franco-alemãs" gradualmente se tornam rotina e servem mesmo de modelo organizacional para os encontros de alto nível dos chefes de Estado e de Governo das Comunidades.

Essas cimeiras entre o presidente francês e o chanceler federal alemão ocorrem ininterruptamente desde 1963, a cada semestre. Os respectivos ministros das Relaçōes Exteriores e da Defesa reúnem-se a cada três meses, secretários de Estado e diretores de departamentos diplomáticos encontram-se mesmo mensalmente. Um tal ritmo, há meio século, não poderia ter deixado de conformar e consolidar uma cooperação exemplar - malgrado arrufos eventuais. A dimensão social e cultural não foi deixada de lado: educação e juventude são previstas como questões estratégicas. Em consequência, surge já em 1964 a Agência Franco-Alemã para a Juventudes, dentre outras entidades bilaterais que se vão constituindo. O Tratado do Eliseu sofreu apenas uma única alteração, em 22 de janeiro de 1988, sob a forma de protocolos adicionais que instituíram novas rotinas de encontros regulares entre as instâncias administrativas governamentais. Foram criados um conselho permanente de segurança e defesa, um conselho franco-alemão de economia e finanças e um conselho franco-alemão de cultura. Percebe-se que a formatação do modo de cooperação entre França e Alemanha Federal estabelece referências operacionais que a arquitetura institucional da União Europeia, em grau certamente maior de complexidade, assumiu.

4 Ver Peter Bender. Die Ostpolitik Willy Brandts oder die Kunst des Selbstverstädlichen. Stuttgart: Rowohlt, 1984, 2a. ed.

5 Deutsch-Französisches Jugendwerk/Office Franco-Allemand de la Jeunesse (<http://www.dfjw.org >). 
Essa cooperação tinha três objetivos estratégicos marcantes:

- A construção de posições comuns em questôes de política externa, no âmbito das Comunidades Europeias, da Otan e das demais instituições multilaterais, com o fito de adotar postura unificada nas negociações das respectivas instâncias decisórias.

- A coordenação das políticas de defesa e de equipamento militar, para adotar estratégias e táticas comuns e para promover integração e intercâmbio de pessoal militar (criação de uma brigada mista franco-alemã ${ }^{6}$ como elemento nuclear de uma futura força armada europeia ${ }^{7}$ ).

- A cooperação intensa em questôes de educação e juventude. Essa cooperação era percebida como urgente, a partir da experiência histórica comum. Um intercâmbio regular de alunos, estudantes, estagiários, professores, operários, etc. contribuiria para vencer as desconfianças mútuas entre os vizinhos. Além do intercâmbio social, as cláusulas estipularam também o fomento do ensino de línguas, o reconhecimento mútuo dos diplomas universitários e a cooperação em pesquisa econômica.

Tais eixos de integração bilateral articulam os campos mesmos em que se dá a formação das políticas europeias, por complexa, lenta e gradual que tenha sido e ainda seja. Uma parte nada negligenciável do acquis communautaire, do tesouro de valores, normas e práticas da União Europeia, decorre do bilateralismo francoalemão e da integração pioneira do Benelux, na qual a Bélgica, a Holanda e o Luxemburgo demonstraram o quanto a união faz a força.

\section{Como na Europa: o Tratado do Eliseu e o sucesso por etapas}

A agenda das relaçôes entre a Europa e os Estados Unidos modificouse na medida em que as Comunidades registraram crescimento econômico e prosperidade. Com o fim dos "trinta gloriosos", em meados dos anos 1970, a contar da primeira grande crise do petróleo (1973), essa agenda ganha nítidos contornos de política econômica internacional. A institucionalização da cooperação econômica franco-alemã, no quadro de uma política monetária comum, do sistema monetário europeu (SME) e do Conselho Franco-Alemão de Economia e Finanças, com o crescente entrelaçamento dos capitais industriais, confere uma força nova à posição negocial europeia perante os Estados Unidos, reforçando assim o modelo franco-alemão de cooperação quanto à sua eficácia no plano da política externa.

6 Formalmente criada na cimeira de Karlsruhe, em 1987, no primeiro mandato de François Mitterrand na presidência francesa.

7 O Eurocorps foi criado por decisão de François Mitterrand e Helmut Kohl por ocasião da cimeira de La Rochelle, em 1992. 
É fato que sempre subsistem modulações, ênfases diferenciadas na política europeia, por parte dos dois parceiros. No entanto, a cooperação entre França e Alemanha (sobretudo depois do ingresso da Grã-Bretanha) manteve sua marca na marcha das Comunidades. Um exemplo notável é o Ato Único Europeu, de 1986, que tornou definitiva a criação de um mercado interno único.

Quanto mais longe iam as competências de Bruxelas, tanto mais claros ficavam seus limites com relação à cooperação franco-alemã. Se esta serviu de inspiração (de modelo, mesmo), o interesse coletivo das Comunidades (União) pouco a pouco se sobrepôs ao predomínio ativo de Paris e de Bonn. Tal evolução não diminuiu, entretanto, o papel exercido pela dupla franco-alemã, plenamente imbuída de sua "missão" de líder integracionista. Instala-se uma nova dinâmica: a dupla Paris-Bonn (a partir de 1990: Paris-Berlim) e "os demais" das Comunidades, entrementes tornados União Europeia. França e Alemanha ainda não encontraram o tom exato de sua parceria em uma Europa a 27. Numa Europa de 6 a 10, o problema manifestamente não se punha. $\mathrm{Na}$ Europa a 15 as questóes de iniciativa, operacionalidade e gestão tornaram-se agudas. A 25 (e, forçosamente, a 27), a fórmula de rearranjo ainda está sendo buscada, e França-Alemanha, se continua a aparecer como uma dupla dinâmica, parece dançar com ritmos diferentes desde o agravamento das crises financeiras de 2008 em diante.

Nas questôes de política de segurança e de defesa, a cooperação no âmbito do Tratado do Eliseu não avançou, até meados da década de 1980. Se não avançou entre França e Alemanha, tampouco avançou no plano europeu. A política externa e de segurança comum (Pesc) ainda na década de 2010 encontra dificuldades de monta para deslanchar. A criação do Alto Representante para a Pesc, em 1999, emitiu um sinal forte de retomada, mas os avanços - por mais otimistas que sejam as manifestações políticas - são modestos. ${ }^{8}$ Se o fracasso da Comunidade Europeia de Defesa, em 1954, não significou o abandono do tema, a questão ficou relegada - sob as circunstâncias adversas da Guerra Fria e da corrida nuclear - a um manifesto segundo plano. A diferença basilar de concepção do papel da Otan e da atuação dos Estados Unidos na Europa e no mundo, persistente entre França e Alemanha, impediu que as boas intenções no plano da política externa, vertentes de defesa e segurança caminhassem no mesmo ritmo. A posição com relação aos Estados Unidos, antes e depois da queda do Muro de Berlim, marcou as diferenças de atitude francesa e alemã e, consequentemente, europeia. A presença da Grã-Bretanha (potência nuclear desde 1957) a partir de 1973 não modificou sensivelmente essa situação.

A França de Georges Pompidou (1969-1974) depois da abertura a leste promovida por Willy Brandt via com desconfiança uma eventual aproximação alemã com a União Soviética, em função da meta da reunificação, devidamente

8 Ver Estevão C. de Rezende Martins. Parcerias Almejadas. Politica externa, segurança, defesa e história na Europa. Belo Horizonte: Fino Traço, 2012. Coleção Relaçôes Internacionais - Série Parcerias Estratégicas com o Brasil. 
inscrita na Lei Fundamental de 1949 como um objetivo vital da Alemanha Federal. ${ }^{9}$ Paris busca então reforçar a vinculação da Alemanha Federal via Comunidades Europeias. Bonn procura, por sua vez, levando em conta sua condição de soberania limitada, que a França incluísse em sua política a leste também os interesses de uma Alemanha francamente aliada ao Ocidente. A circunstância desses receios ou expectativas levou a uma gradual intensificação da política de segurança (atuação na Conferência sobre Segurança e Cooperação na Europa, Helsinque, 1973; dupla resolução da Otan em 1979; cooperação reforçada no âmbito da União da Europa Ocidental, nos anos 1980, de modo a ativar a cooperação política europeia), que conduz aos protocolos adicionais de 1988 e à criação do Conselho Franco-Alemão de Defesa e Segurança. O paralelismo com as iniciativas comunitárias é patente.

A parceria franco-alemã e o papel por ela desempenhado no concerto europeu possuem primordialmente razões específicas de política externa e de política de poder. Não se pode ignorar, contudo, que essa parceria se revestiu, na maior parte do tempo, das personalidades dos respectivos chefes de Estado e de Governo, cuja sintonia contribui para a eficiência das consultas e das decisões.

Para além dos pertencimentos político-partidários, o diálogo dos dirigentes foi fundamental. Não se trata de lançar mão de uma explicação psicologista, mas de reconhecer o caráter crescentemente supradoméstico do entendimento entre os governantes. De Gaulle e Adenauer, ambos homens do fim do século 19 e início do século 20, formados sob a influência da democracia cristã, sabem que não há futuro para a Europa sem a reconciliação franco-alemã. Entre Georges Pompidou e os dirigentes alemães, em especial Willy Brandt, entre 1969 e 1973, a sintonia é menor, reduzida ao estrito necessário, embora sem ruptura. Com Giscard d'Estaing (1974-1981) e Helmut Schmidt (1972-1982), a harmonia é forte e ajuda os respectivos países, como a Europa, a enfrentar as crises econômicas e políticas, como a do petróleo e a do terrorismo. Entre François Mitterrand (1981-1995) e Helmut Kohl (1982-1998), embora pertencentes a tradiçōes políticas tradicionalmente opostas, a interação é clara, eficiente e mesmo surpreendente. Essa sintonia foi fundamental para fazer avançar a União Europeia e para coroar a unificação alemã em 1990. O apoio de ambos foi decisivo para o grande sucesso organizacional da União na presidência do francês Jacques Delors (1985-1995) na Comissão Europeia. O mesmo não pode ser dito da relação entre Jacques Chirac (1995-2007) e Gerhard Schröder (1998-2005), com os sinais políticos trocados. Como no caso de Willy Brandt, Schröder manteve a relação com a França em fogo brando, do que decorreu certa perda de ritmo nos processos europeus.

Com efeito, a influência franco-alemã, pelo enfraquecimento de sua coesão e pela diluição da constelação de poder no seio da União Europeia (tanto na

9 Tenha-se presente que a República Federal da Alemanha se entendia como um provisorium, até a almejada reunificação. Assim, o preâmbulo da Lei Fundamental (promulgada em 23 de maio de 1949) afirma que a Alemanha Federal age também em nome dos demais alemães que não puderam participar do processo decisório de então e que o objetivo de todo o povo alemão é decidir livremente da unidade e da liberdade da Alemanha (http://www.documentarchiv.de/brd/1949/grundgesetz.html). 
Convenção para um tratado constitucional quanto no forte alargamento de 2004), recuou fortemente. $\mathrm{O}$ fato de ter havido uma longa coabitação política na França, entre 1997 e 2002, com o governo de maioria socialista de Lionel Jospin, certamente contribui para uma diminuição do ritmo. Poder-se-ia pensar que ocorreria uma sintonia eventualmente maior com os social-democratas alemães, mas não foi o caso. A dupla Nicolas Sarkozy (2007-2012) e Angela Merkel (desde 2005) somente começou a apresentar maior convergência quando a crise do euro se agravou. É interessante notar que nenhuma outra "dupla" de dirigentes europeus se destacou na mesma medida dos governantes franceses e alemães. No período pós-queda do Muro de Berlim, nota-se que são amiúde dirigentes europeus oriundos dos países pequenos da União que assumem cargos de importância vital em Bruxelas (Luxemburgo, Bélgica, Portugal).

Não é apenas na integração no plano dos mais altos dirigentes e da burocracia ministerial que a conexão Paris-Berlim (e, com isso, a galáxia Europa) funciona e impulsiona. A cooperação desce, mesmo se nem sempre percebida com clareza, até o quotidiano da sociedade. Há intercâmbios entre municípios, associações profissionais, alunos de escolas, estudantes universitários, trabalhadores do comércio e da indústria. A parceria entre cidades tem se mostrado especialmente eficaz para o aumento do conhecimento mútuo e a eventual superação dos preconceitos e estereótipos por tanto tempo alimentados na história europeia. ${ }^{10}$

$\mathrm{O}$ cerne do Tratado do Eliseu não se restringe, por conseguinte, à cooperação formal intergovernamental. O engajamento da sociedade civil, com a incomensurável diversidade de suas redes, ganhou mais peso desde o início do processo de reconciliação entre os dois países. Esse processo tem resultados sociais e culturais de grande valor, pois a consideração mútua dos cidadãos de um e de outro lado do Reno é alta. Os levantamentos de opinião situam a "boa imagem" das relações franco-alemãs acima de $80 \%$ nas duas sociedades (sem alteração notável desde a reunificação em $1990^{11}$ ), percebidas como importantes, essenciais mesmo para o processo europeu de integração.

\section{Mudanças desde a reunificação}

O fim do conflito leste-oeste acarreta obviamente uma modificação importante nas relações franco-alemãs. Não se poderia falar em cesura, como o fizeram alguns comentaristas à época, mas certamente um marco evolutivo de grande alcance

\footnotetext{
10 A relevância da geminação entre cidades é uma questão pacífica no âmbito europeu. A título de exemplo de sua importância, pode-se mencionar a questão do deputado europeu alemão Michael Gahler, em 1999, à Comissão, sobre os meios de apoio financeiro ao desenvolvimento das parcerias. A resposta da comissária Viviane Reding reforça o reconhecimento dessa importância (Pergunta escrita E-1979/1999). Em 2012, funcionam mais de 2.200 parcerias entre cidades e coletividades locais francesas e alemãs (que correspondem a $37 \%$ de todas as parcerias do tipo, na Europa inteira. Ver Infobrief/La lettre d'information DFJW/OFAJ, 1.2012, p. 16).

11 Ver, por exemplo, as referências do jornal Frankfurter Rundschau em 22 de setembro de 2012 (<http://www.fr-online.de/politik/50-jahre-deutsch-franzoesische-freundschaft-freunde-und-partner, 1472596,17890286.html>).
} 
sob o signo da perseverança e da continuidade. ${ }^{12}$ A reunificação alemã decorre de uma alteração notável da cena internacional, com a União Soviética em seus estertores agônicos e o sistema da Guerra Fria a esvair-se. Tornada viável pelo Tratado Dois Mais Quatro, de setembro de 1990, a reunificação de certa maneira desbanca França e Grã-Bretanha do envelhecido pedestal de "potências vencedoras da 2a Guerra Mundial”. Nesse tratado joga-se a última pá de cal sobre a ordem do imediato pós-guerra na Europa. O esfacelamento subsequente da URSS e a liberdade política e econômica recobrada de inúmeros países do centro e do leste europeus na década seguinte arrematam essa extraordinária virada. Nenhum político ou analista adiantara tal previsão quando da ascensão de Mikhail Gorbachev ao poder, em 1985.

A correlação geopolítica de poder da dupla França-Alemanha obviamente alterou-se. Como modificada foi a posição relativa da União Europeia no mundo reordenado, ou como de início se pensou, desordenado. Nessa dupla, a Alemanha foi durante longas décadas linha auxiliar da política externa "grandiosa" ("de la grandeur de la France", expressão cara a de Gaulle e nada estranha a seus sucessores). Efetivada a reunificação, a Alemanha tornou-se o estado-membro da União com o maior território, com a maior população e com a maior economia. Um redimensionamento tanto do bilateralismo franco-alemão quanto do peso relativo da Alemanha na equação europeia tornou-se, por sua vez, inevitável. O alargamento a leste da União colocou a Alemanha política e geograficamente no centro do sistema. $\mathrm{O}$ oeste em que a França foi central durante meio século evoluiu para uma posição menos decisiva. O que antes era "Europa Ocidental" é doravante, "simplesmente", "Europa". A nova constelação europeia conferiu à Alemanha uma agência até então menos destacada. A França - em parte também em decorrência de suas incoerências políticas internas, pontuadas de fraturas parcialmente ideológicas em boa parte anacrônicas (oposição entre "socialismo" e "conservadorismo" e entre "nacionalismo" e "entreguismo", dentre outras) - vê diminuir sua influência. A adesão incondicional da Alemanha ao programa e a seus compromissos com e na Uniāo Europeia levou-a a atuar com particular prudência, poupando a hipersensibilidade política francesa e respeitando o caráter comunitário da arquitetura europeia. Ao longo de duas décadas, percebe-se que a Alemanha continua a manter posiçóes firmes, notadamente em termos de política econômica, monetária e financeira, de disciplina orçamentária e de engajamento europeu. Pode-se dizer que a Alemanha da década de 2010 é talvez a campeã do europeísmo, malgrado a tradição francesa de Jean Monnet e Robert Schuman.

Para não colocar em risco uma parceria tão bem-sucedida, na década de 1990, Berlim e Paris apostaram em mais Europa. O Tratado de Maastricht, em 1992, firmou a institucionalização da União Europeia, a criação da união econômica e

12 Ver, por exemplo, o comentário do deputado europeu francês Jean-Louis Bourlanges, no semanário alemão Die Zeit (25 de março de 1994: <http://www.zeit.de/1994/13/neue-visionen-suchen>). 
monetária e a introdução da moeda única. O euro é um projeto franco-alemão, tornado viável nas condiçóes da parceria redimensionada ao longo do período 1990-2000. A tática de política "externa” na política "interna” europeia das décadas de 1990-2000 foi uma nova utilização de uma estratégia aplicada, nos anos 1950, à novel República Federal da Alemanha: a da inclusão, do enquadramento de perto. Assim como em seu nascedouro, a Alemanha foi vinculada às alianças ocidentais na forma da Otan e das Comunidades Europeias, ora se atrela a Alemanha unificada ainda mais à União Europeia e a sua rede de alianças. A profissão de fé europeia da Alemanha foi sem falhas: o marco alemão, moeda de referência no continente e no mundo, instrumento de política econômica internacional, foi sacrificado e incorporado ao euro. A cooperação com a França, malgrado certas passagens a frio conforme os dirigentes nos cargos, é preservada e segue um fator decisivo no sistema motriz da União.

A moeda única, mesmo em se tratando de uma construção ciclópica e ousada, não basta para homogeneizar as divergências políticas entre Paris e Berlim. No plano da política externa europeia, a Alemanha pressionou para o alargamento a leste e a sudeste ocorrer com rapidez. Certamente a lógica alemã é a mesma que viu aplicada a si: Europa emoldura, preserva, vincula, faz depender. Com isso o risco de deriva política dos países anteriormente sob o jugo do regime soviético desapareceria ou, ao menos, diminuiria sensivelmente. Nesse particular a Alemanha persevera nos princípios de desanuviamento político firmados na Ostpolitik de Willy Brandt nos anos 1970.

A França, diversamente, considera prioritária a reforma interna da União, com o aprofundamento de suas instituições e a revisão de suas regras de funcionamento, cujas falhas tornavam-se cada vez mais patentes nos anos 1990. A política algo vetusta de grandeza nacional dos diversos governos franceses também visava a evitar um crescimento acelerado da influência alemã por si mesma. Ainda antes da adesão da Suécia, da Finlândia e da Áustria, em 1995, já se falara em um afrouxamento da relação franco-alemã e de uma diluição da União pela adesão em massa de países (do leste e do sudeste europeus) "ainda em fase de reconstituição". ${ }^{13}$

Com tal cenário político, a cooperação no interior da União Europeia se caracterizaria - como efetivamente veio a ocorrer nos últimos 20 anos por um incremento do processo intergovernamental de decisão. Embora o intergovernamentalismo ainda prevaleça, alemães e franceses têm consciência de que iniciativas teriam de ser tomadas, em especial quando o alargamento de 2004 e o bloqueio da convenção europeia de 2005 dificultaram o avanço do sistema de ponderação decisória entre os estados-membros e em nada ajudaram a aumentar o

13 A agência europeia de estatística (Eurobarometer) publica regularmente enquetes de opinião acerca das inúmeras variáveis de satisfação social na Uniāo (tanto interna quanto europeiamente); a mais recente é de julho de 2012: <http://ec.europa.eu/public_opinion/archives/eb/eb77/eb77_first_en.pdf>, na qual se visualiza (para os últimos dez anos, aproximadamente) a evolução do "estado de espírito" dos cidadãos - que acompanha de perto os cenários de euforia ou de crise. 
papel do Parlamento Europeu ou de outras instâncias de representação popular. As iniciativas franco-alemãs, mesmo se numerosas, começam a perder algum fôlego. Isso se dá tanto no plano das questôes políticas (somente dois países rejeitaram o projeto de convenção europeia: a França e a Holanda) quanto no da política econômica e externa. O primeiro-ministro e ministro luxemburguês das Finanças, Jean-Claude Juncker, europeísta convicto e reconhecido, exprime sem muita hesitação certa fadiga com relação à dupla franco-alemã, percebida por vezes como hiperativa. ${ }^{14}$

Desde o Tratado de Maastricht (1992) o dinamismo da dupla franco-alemã diminuiu o ritmo. Uma divergência importante surgiu na cimeira de Nice, em 2000, a propósito da redistribuição dos assentos no Conselho de Ministros da União. A França recusou-se terminantemente a admitir que a Alemanha obtivesse um peso maior, mesmo se meramente simbólico, em consequência de seu maior número de cidadãos. A posição francesa, marcada por uma atitude conservadora, considerava que a paridade absoluta até então vigente seria o penhor de um sucesso de mais 40 anos, que poderia ficar comprometido. Como de costume, as negociações levaram a compromissos que mantiveram abertas as possibilidades da União, embora aquém do que teria sido necessário para prevenir as dificuldades operacionais previsíveis no futuro imediato, pois para o fim de 2002 ficou marcada a rodada de adesões que se torna efetiva, afinal, em 2004.

O Tratado de Nice introduziu modificações nos seguintes campos:

- Alargamento: a União programa a admissão de novos estados-membros a partir do final de 2002, atendidos os requisitos para a adesão.

- Decisões por maioria no Conselho de Ministros da União: cerca de 40 artigos do Tratado da União Europeia são modificados. A unanimidade continua exigida para questôes cruciais como tributação. Política externa, de segurança e de defesa continua entravada; será necessário esperar o Tratado de Lisboa, em 2009.

- Ponderação dos votos: Alemanha, França, Itália e Grã-Bretanha pesam 29 cada. A Espanha 27 (mesmo peso previsto para a candidata Polônia).

14 Le Monde, 12 de outubro de 2011. Le chef de file des ministres des finances de la zone euro, le Luxembourgeois Jean-Claude Juncker, critique la multiplication des initiatives bilatérales de la France et de l'Allemagne. "Tout ce que décident la France et l'Allemagne ne devient pas automatiquement une décision de l'Union européenne, dit M. Juncker au quotidien allemand Handelsblatt. Si vous regardez les douze derniers mois, environ $70 \%$ des propositions franco-allemandes n'ont pas abouti à une décision. " Ses propos, recueillis lundi par le journal, interviennent après une rencontre entre le président français Nicolas Sarkozy et la chancelière Angela Merkel à Berlin dimanche, au terme de laquelle les deux dirigeants ont convenu de faire des propositions dans les semaines à venir, notamment sur la recapitalisation des banques. Ce n'est pas la première fois que M. Juncker s'irrite des initiatives du tandem franco-allemand, qui a pris pour habitude ces derniers mois de faire des annonces bilatérales en matière de lutte contre la crise de la dette en zone euro. Le gouvernement économique de la zone euro, tel que les pays membres de l'Union monétaire se sont engagés à le mettre en œuvre, " ne doit pas être un commando franco-allemand », poursuit M. Juncker. "L’expérience montre que cela sera principalement un commando français ", a-t-il ajouté, "mais coordination de la politique économique ne peut pas vouloir dire : j'atterris à Paris et je roule à l'aveuglette derrière une voiture marquée 'follow me' [suivez-moi] ». (<http://www. lemonde.fr/europe/article/2011/10/12>). 
- Comissão Europeia: com a adesão programada de mais 12 membros, a Comissão passará a ser composta por apenas um comissário por país. Acima de 27 estados-membros, será necessária uma revisão. Reforça-se o poder do Presidente da Comissão.

- Fomento da cooperação: instituiu-se procedimento simplificado para a formação de grupos de estados-membros para a cooperação em campos específicos. É o caso do Grupo do Euro, menor do que o pleno da União. Também quanto a esse aspecto precisou-se do Tratado de 2009.

- Desdobramentos após a cimeira de Nice: com a adesão prevista, programase para 2004 uma conferência dos chefes de Estado e de Governo sobre a partilha de direitos e deveres entre a União e os estados-membros.

- Carta dos direitos fundamentais dos cidadãos da União: sem vincular juridicamente os estados-membros, pois revestida de caráter declaratório, é projetada como fundamento da futura constituição europeia, a ser elaborada pela Convenção convocada para 2002.

- Alguns outros tópicos conjunturais foram também ressaltados: combate à epidemia da "vaca louca" (sobretudo por causa dos custos financeiros); modernização do "modelo europeu de estado de bem-estar social" (também com vistas ao elevado custo financeiro que já se vê pesar nos orçamentos nacionais); indicação de uma política militar comum (timidamente, por haver a Grã-Bretanha vetado qualquer menção que pudesse ser interpretada como debilitação da Otan).

A França conseguiu, ao final das contas, ganho de causa, com a manutenção da paridade com a Alemanha. O preço foi alto e é pago ainda até os dias de hoje. A prevalência da paridade, combinada com a unanimidade para determinados temas (mesmo que se tenha flexibilizado outros), plantou o germe dos obstáculos decisórios que atingiram o desenvolvimento da política externa e de segurança comum, dentre outras políticas. Paridade e unanimidade possuem forte valor simbólico (de interesse igualmente da Grã-Bretanha), inclusive para a constante ação da dupla franco-alemã, ao menos desde a perspectiva nacional autossuficiente de Paris, que não vê com entusiasmo algum o crescimento de Berlim - malgrado a retórica oposta. A insistência francesa nesse binômio tem igualmente fundamento em uma concepção divergente da alemã quanto ao formato final a ser adotado pela União Europeia. Com efeito, Berlim contempla a União Europeia desde uma perspectiva federal (o sucesso organizacional, político, econômico e financeiro da República Federal da Alemanha certamente sustenta tal posição). A França, numa sobrevivência política surpreendentemente longeva do gaullismo político, insiste na tradição do estado-nação homogêneo e centralizado. Com isso, as instituições europeias seriam meras delegadas de seus membros, estados-nações, uma "Europe des patries", pois uma "nação europeia" não existiria. Embora as decisões de fato 
adotadas ao longo do processo europeu não reforcem a posição francesa, ela continua presente, ao menos no discurso político de seus dirigentes e, em parte, na atuação de Paris nos grêmios europeus. ${ }^{15}$

\section{Perspectivas para além do cinquentenário}

Malgrado os avanços notáveis da União, notadamente com a recuperação negociada de parte do Tratado Constitucional de 2004, na forma do Tratado de Lisboa, de $1^{\circ}$ de dezembro de 2009 , as parcerias entre estados-membros seguem relevantes. A mais antiga é certamente a franco-alemã. Desde 2008 acentuaramse nessa parceira os sinais conflitantes, conquanto não impedientes, próprios ao seu longo itinerário. De um lado, permanecem as concepçôes divergentes quanto ao formato final da União Europeia. De outro, como assinalado por Jean-Louis Juncker, certo ativismo "monodirecional", concentrado na crise persistente dos estados-membros com sérios problemas de endividamento público e de orçamento, que abala o euro.

Um cenário possível, para além dos 50 anos de um tratado do qual, seguramente, não há volta é o reforço do intergovernamentalismo (com suas óbvias consequências nocivas para o aprofundamento institucional europeu). Uma paridade mantida, mesmo de forma mitigada, em uma Europa altamente diversificada, pode acarretar - como parece ser o caso em 2012 - uma fronda dos pequenos e médios estados contra a hegemonia franco-alemã. De outro lado, a manifesta hostilidade do governo francês sob François Hollande às iniciativas franco-alemãs de 2011 e do primeiro quadrimestre de 2012 contribuem para um 'estranhamento' entre Paris e Berlim. Desse "estranhamento" se aproveita a Grã-Bretanha, cujo curso paraeuropeu, sob governo trabalhista ou conservador, continua a destoar no concerto da União. A recusa britânica de subscrever o Tratado de Estabilidade, Coordenação e Governança é mais um episódio nessa longa história de exceçôes.

De toda maneira, o consenso franco-alemão, tal como definido no Tratado do Eliseu, se encontra em dificuldades nos anos 2010, não perde por isso sua característica de "pauta" da União Europeia em sua evolução até o presente. No início dos anos 2000, a consciência de que era necessária uma nova dinâmica para essa dupla, como para a Europa mesma, era clara ao então presidente francês Jacques Chirac (1995-2007) como ao então chanceler federal Gerhard Schröder

$15 \mathrm{O}$ novo presidente francês, François Hollande, ainda candidato, perguntado a propósito do reforço das instituições europeias, declarou ao semanário Le nouvel Observateur, em 16 de abril de 2012: “...Tout cela devra être engagé en renforçant les contrôles démocratiques sur les décisions européennes. [...] J'ai une ambition ardente pour l'Europe : renouer la confiance avec les peuples." [grifo meu] <http://tempsreel.nouvelobs.com/ election-presidentielle-2012/20120416.OBS6301/politique-etrangere-ce-qu-en-dit-francois-hollande.html>. Ainda não há sinais claros, desde que assumiu a presidência, da direção que o governo francês tomará, uma vez que a crise financeira e orçamentária continua a absorver todos os esforços, em torno do Tratado de Estabilidade, Coordenação e Governança (TECG), de 2 de março de 2012, em fase de ratificação por 25 dos 27 estadosmembros (não o firmaram a Grã-Bretanha e a República Tcheca). 
(1998-2005). Uma refundação das relações franco-alemãs, como da União Europeia, parece ser uma exigência dos tempos - ao menos consta da Agenda FrancoAlemã 2020, estabelecida como programa de ação do Conselho Franco-Alemão de Ministros, por Nicolas Sarkozy e Angela Merkel, em 4 de fevereiro de 2010. A Agenda cobre seis campos de ação: (1) economia, finanças, emprego; (2) energia, clima, diversidade biológica; (3) crescimento, inovação, pesquisa, educação, universidade; (4) política externa, de defesa e de segurança; (5) proximidade com os cidadãos; (6) moldura institucional.

A correlação entre a parceria franco-alemã e a organização da Europa - ao menos na convicção de Paris e Berlim - fica patente, como se pode ler no preâmbulo da agenda 2020:

Desejamos uma Europa que atue com ambição e determinação, no respeito das diferenças entre os estados-membros e na observância do princípio de subsidiaridade. Para alcançar tal objetivo, estamos decididos a fazer o que for necessário para extrair o máximo do potencial das instituiçōes reformadas pelo Tratado de Lisboa, tornando a União Europeia ainda mais atuante, cuja voz seja ouvida mundo afora. Agora, que o debate sobre as instituiçôes europeias já passou, queremos que a Europa empenhe toda a sua força e toda a sua ação em benefício de seus cidadãos e de suas empresas, preservando o meio ambiente como nosso patrimônio comum. Precisamos fazer tudo o que for necessário para promover um crescimento forte e sustentável na Europa e possibilitar que a União saia da crise atual fortalecida, de modo que o modelo europeu da economia social de mercado se mantenha. Para tal fim, a Europa deve adotar ainda este ano [2010] uma nova estratégica econômica para a próxima década, na qual sejam definidas metas ambiciosas para 2020 e viabilizada uma coordenação bem-sucedida da economia nos próximos meses e anos. A Europa precisa reforçar e modernizar sua política, ganhar novos impulsos, de forma a garantir a segurança energética, combater o aquecimento global, regular os fluxos migratórios e desenvolver metas ambiciosas comuns para o espaço global. ${ }^{16}$

A Europa assim almejada é uma realidade aberta, cuja identidade coletiva ainda anda trôpega, hesitante entre o intergovernamentalismo persistente e a, aparentemente inevitável, federalização para além dos Estados e de suas histórias. A Europa, ao praticar uma política externa comum, inspira-se das políticas "internas" (que um dia foram externas), e espera dela um efeito agregador ad intra, por contraste com a conjuntura global, nomeadamente a não europeia.

À maneira da parceria franco-alemã, cuja relevância histórica no processo de integração não deixa margem a dúvida, a União Europeia precisa ainda integrar as dimensōes nacionais e infranacionais em uma equação supranacional, em que

16 Ver <http://www.bundesregierung.de/Content/DE/Artikel/2010/02/2010-02-04-deutsch-franzoesischeagenda-2020.html>. 
as diversas não se diluam nem se transformem em obstáculo à coordenação e à governança comunitária. Sistema de governo, tipo das relações institucionais na União, consciência e cultura europeia, homogeneização crescente da estrutura normativa (em especial em matéria financeira e orçamentária), equalização das assimetrias econômicas e educacionais, segurança e defesa, harmonização da ação externa (para além das intervençôes pontuais em questões humanitárias e de preservação da paz) - tantos e mais pontos que desafiam as parcerias dentro e fora da União.

Parcerias análogas à franco-alemã não surgiram, até hoje, no âmbito da União Europeia. Parcerias de outra natureza existem, como a do Benelux. Parcerias ad hoc pertencem mesmo à natureza das constelações mutantes de interesses localizados, como no triste exemplo do precipitado e irrefletido apoio à operação de guerra dos Estados Unidos, no governo George W. Bush, contra o Iraque.

A complexa amplitude de negociação da União, cuja perseverança tem dado sobejas mostras de êxito, conduziu ao Tratado de Lisboa, em 2009, como um notável desempenho de recuperação dos percalços dos quatro a cinco anos anteriores. Nesse tratado, que renova, reestrutura e consolida o longo itinerário até então, a política externa e de segurança comum ganha afinal posição sistematizada e de destaque, mesmo se não desabrochou muito além do espaço nobre que recebeu nos tratados.

As Tabelas 1 e 2 a seguir reúnem excertos dos tratados, protocolos e declaraçóes mais recentes, trazidos para ilustrar, nos textos em vigor, as duas reflexóes aqui apresentadas. A primeira reflexão, e mais ampla, diz respeito ao caráter exemplar da parceria franco-alemã, no que inspirou a União. As passagens a ela remetentes estão marcadas em itálico. A segunda reflexão, acessória, indica os numerosos e persistentes entraves que se impõem à política externa e de segurança comum. Os trechos quanto a esse ponto estão em negrito.

Tabela 1. Versão consolidada dos Tratados Europeus (Lisboa) ${ }^{17}$.

\begin{tabular}{|l|l|}
\hline $\begin{array}{l}\text { Preâmbulo } \\
\text { TUE }\end{array}$ & $\begin{array}{l}\text { RESOLVIDOS a executar uma política externa e de segurança que inclua a definição } \\
\text { gradual de uma política de defesa comum que poderá conduzir a uma defesa comum, } \\
\text { de acordo com as disposiçōes do artigo 42, fortalecendo assim a identidade europeia } \\
\text { e a sua independência, em ordem a promover a paz, a segurança e o progresso na } \\
\text { Europa e no mundo, }\end{array}$ \\
\hline Art. 15 & $\begin{array}{l}\text { O Presidente do Conselho Europeu assegura, ao seu nível e nessa qualidade, a } \\
\text { representação externa da União nas matérias do âmbito da política externa e de } \\
\text { segurança comum, sem prejuízo das atribuições do Alto Representante da União } \\
\text { para os Negócios Estrangeiros e a Política de Segurança. }\end{array}$ \\
\hline Art. 17 & $\begin{array}{l}\text { Com exceção da política externa e de segurança comum e dos restantes casos previstos } \\
\text { nos Tratados, a Comissão assegura a representação externa da União. }\end{array}$ \\
\hline
\end{tabular}

17 Edição oficial em língua portuguesa, disponível em http://bookshop.europa.eu/is-bin/INTERSHOP.enfinity/ WFS/EU-Bookshop-Site/pt_PT///EUR/ViewPublication-Start?PublicationKey=QC3209190. 


\begin{tabular}{|c|c|}
\hline Art. 18 & $\begin{array}{l}\text { 2. O Alto Representante conduz a política externa e de segurança comum da União. } \\
\text { Contribui com as suas propostas para a elaboração dessa política, executando-a na } \\
\text { qualidade de mandatário do Conselho. Atua do mesmo modo no que se refere à } \\
\text { política comum de segurança e defesa. }\end{array}$ \\
\hline Art. 22 & $\begin{array}{l}\text { As decisões do Conselho Europeu sobre os interesses e objetivos estratégicos da União } \\
\text { incidem nos domínios da política externa e de segurança comum e noutros domínios } \\
\text { que se insiram no âmbito da ação externa da União. Essas decisóes podem dizer respeito } \\
\text { às relaçôes da União com um país ou uma região ou seguir uma abordagem temática. } \\
\text { Definem a sua duração e os meios a facultar pela União e pelos Estados-Membros. } \\
\text {.. } \\
\text { 2. O Alto Representante da União para os Negócios Estrangeiros e a Política de } \\
\text { Segurança, no domínio da política externa e de segurança comum, e a Comissão, nos } \\
\text { restantes domínios da ação externa, podem apresentar propostas conjuntas ao Conselho. }\end{array}$ \\
\hline Art. 24 & $\begin{array}{l}\text { 1. A competência da União em matéria de política externa e de segurança comum } \\
\text { abrange todos os domínios da política externa, bem como todas as questões relativas à } \\
\text { segurança da União, incluindo a definição gradual de uma política comum de defesa } \\
\text { que poderá conduzir a uma defesa comum. } \\
\text { A política externa e de segurança comum está sujeita a regras e procedimentos } \\
\text { específicos. É definida e executada pelo Conselho Europeu e pelo Conselho, } \\
\text { que deliberam por unanimidade, salvo disposição em contrário dos Tratados. } \\
\text { Fica excluída a adoção de atos legislativos. Esta política é executada pelo Alto } \\
\text { Representante da União para os Negócios Estrangeiros e a Política de Segurança e } \\
\text { pelos Estados-Membros, nos termos dos Tratados. } \\
\text { 2. No quadro dos princípios e objetivos da sua ação externa, a União conduz, define } \\
\text { e executa uma política externa e de segurança comum baseada no desenvolvimento } \\
\text { da solidariedadepolítica mútua entre os Estados-Membros, na identificação das questões } \\
\text { de interesse geral e na realização de um grau de convergência crescente das açôes dos } \\
\text { Estados-Membros. } \\
\text { 3. Os Estados-Membros apoiarão ativamente e sem reservas a política externa e de } \\
\text { segurança da União, num espírito de lealdade e de solidariedade mútua, e respeitam a } \\
\text { ação da União neste domínio. }\end{array}$ \\
\hline Art. 25 & $\begin{array}{l}\text { A União conduz a política externa e de segurança comum: } \\
\text { a) Definindo as orientações gerais; } \\
\text { b) Adotando decisões que definam: } \\
\text { i) As ações a desenvolver pela União; } \\
\text { ii) As posições a tomar pela União; } \\
\text { iii) As regras de execução das decisões referidas nas subalíneas i) e ii); e } \\
\text { c) Reforçando a cooperação sistemática entre os Estados-Membros na condução da sua } \\
\text { política. }\end{array}$ \\
\hline
\end{tabular}




\begin{tabular}{|c|c|}
\hline Art. 26 & $\begin{array}{l}\text { 1. O Conselho Europeu identifica os interesses estratégicos da União, estabelece os } \\
\text { objetivos e define as orientaçóes gerais da política externa e de segurança comum, } \\
\text { incluindo em matérias com implicações no domínio da defesa. O Conselho Europeu } \\
\text { adota as decisões necessárias. } \\
\text { Se um acontecimento internacional assim o exigir, o Presidente do Conselho Europeu } \\
\text { convocará uma reunião extraordinária do Conselho Europeu, a fim de definir as linhas } \\
\text { estratégicas da política da União relativamente a esse acontecimento. } \\
\text { 2. O Conselho elabora a política externa e de segurança comum e adota as decisōes } \\
\text { necessárias à definição e execução dessa política, com base nas orientações gerais } \\
\text { e linhas estratégicas definidas pelo Conselho Europeu. O Conselho e o Alto } \\
\text { Representante da União para os Negócios Estrangeiros e a Política de Segurança } \\
\text { asseguram a unidade, coerência e eficácia da ação da União. } \\
\text { 3. A política externa e de segurança comum é executada pelo Alto Representante e } \\
\text { pelos Estados-Membros, utilizando os meios nacionais e os da União. }\end{array}$ \\
\hline Art. 27 & $\begin{array}{l}\text { 1. O Alto Representante da União para os Negócios Estrangeiros e a Política de } \\
\text { Segurança, que preside ao Conselho dos Negócios Estrangeiros, contribui com as } \\
\text { suas propostas para a elaboração da política externa e de segurança comum e assegura } \\
\text { a execução das decisões adotadas pelo Conselho Europeu e pelo Conselho. } \\
\text { 2. O Alto Representante representa a União nas matérias do âmbito da política } \\
\text { externa e de segurança comum. Conduz o diálogo político com terceiros em nome da } \\
\text { União e exprime a posição da União nas organizaçôes internacionais e em conferências } \\
\text { internacionais. } \\
\text {... }\end{array}$ \\
\hline Art. 30 & $\begin{array}{l}\text { 1. Qualquer Estado-Membro, o Alto Representante da Uniäo para os Negócios Estrangeiros } \\
\text { e a Politica de Segurança, ou o Alto Representante com o apoio da Comissäo, podem } \\
\text { submeter ao Conselho todas as questöes do âmbito da politica externa e de segurança } \\
\text { comum e apresentar-lhe, respectivamente, iniciativas ou propostas. } \\
\text {... }\end{array}$ \\
\hline Art. 32 & $\begin{array}{l}\text { Os Estados-Membros concertar-se-ão no âmbito do Conselho Europeu e do } \\
\text { Conselho sobre todas as questôes de política externa e de segurança que se revistam } \\
\text { de interesse geral, de modo a definir uma abordagem comum. Antes de empreender } \\
\text { qualquer ação no plano internacional ou de assumir qualquer compromisso que possa } \\
\text { afetar os interesses da União, cada Estado-Membro consulta os outros no Conselho } \\
\text { Europeu ou no Conselho. Os Estados-Membros asseguram, através da convergência das } \\
\text { suas açôes, que a União possa defender os seus interesses e os seus valores no plano } \\
\text { internacional. Os Estados-Membros são solidários entre si. }\end{array}$ \\
\hline Art. 36 & $\begin{array}{l}\text { O Alto Representante da União para os Negócios Estrangeiros e a Política de } \\
\text { Segurança consulta regularmente o Parlamento Europeu sobre os principais } \\
\text { aspectos e as opções fundamentais da política externa e de segurança comum e da } \\
\text { política comum de segurança e defesa, e informa-o sobre a evolução destas políticas. } \\
\text { O Alto Representante vela por que as opinióes daquela instituição sejam devidamente } \\
\text { tidas em conta. Os representantes especiais podem ser associados à informação do } \\
\text { Parlamento Europeu. }\end{array}$ \\
\hline
\end{tabular}




\begin{tabular}{|c|c|}
\hline Art. 38 & $\begin{array}{l}\text { Sem prejuízo do disposto no artigo } 240 \text { do Tratado sobre o Funcionamento da União } \\
\text { Europeia, um Comitê Político e de Segurança acompanhará a situação internacional } \\
\text { nos domínios pertencentes ao âmbito da política externa e de segurança comum e } \\
\text { contribuirá para a definição das políticas, emitindo pareceres destinados ao Conselho, } \\
\text { a pedido deste, do Alto Representante da União para os Negócios Estrangeiros } \\
\text { e a Política de Segurança ou por sua própria iniciativa. O Comitê acompanhará } \\
\text { igualmente a execução das políticas acordadas, sem prejuízo das atribuiçóes do Alto } \\
\text { Representante. }\end{array}$ \\
\hline Art. 40 & $\begin{array}{l}\text { A execução da política externa e de segurança comum não afeta a aplicação dos } \\
\text { procedimentos e o âmbito respectivo das atribuições das instituições previstos nos } \\
\text { Tratados para o exercício das competências da União enumeradas nos artigos 3.o a } \\
\text { 6.o do Tratado sobre o Funcionamento da União Europeia. }\end{array}$ \\
\hline Art. 41 & $\begin{array}{l}\text { 3. O Conselho adota uma decisão que estabelece os procedimentos específicos } \\
\text { para garantir o rápido acesso às dotaçóes do orçamento da União destinadas ao } \\
\text { financiamento urgente de iniciativas no âmbito da política externa e de segurança } \\
\text { comum, nomeadamente às atividades preparatórias das missóes referidas no n.o } 1 \text { do } \\
\text { artigo } 42 \text { e no artigo } 43 \text {. O Conselho delibera após consulta ao Parlamento Europeu. }\end{array}$ \\
\hline Art. 42 & $\begin{array}{l}\text { 1. A política comum de segurança e defesa faz parte integrante da política externa e } \\
\text { de segurança comum. A política comum de segurança e defesa garante à União uma } \\
\text { capacidade operacional apoiada em meios civis e militares. A União pode empregá- } \\
\text { los em missóes no exterior a fim de assegurar a manutenção da paz, a prevenção de } \\
\text { conflitos e o reforço da segurança internacional, de acordo com os princípios da Carta } \\
\text { das Nações Unidas. A execução destas tarefas assenta nas capacidades fornecidas pelos } \\
\text { Estados-Membros. }\end{array}$ \\
\hline
\end{tabular}

Tabela 2. Tratado sobre o funcionamento da União Europeia.

\begin{tabular}{|c|c|}
\hline Art. $2^{\circ}$ & $\begin{array}{l}\text { 4. A União dispõe de competência, nos termos do Tratado da União Europeia, } \\
\text { para definir e executar uma política externa e de segurança comum, inclusive } \\
\text { para definir gradualmente uma política comum de defesa. }\end{array}$ \\
\hline Art. 218 & $\begin{array}{l}\text { 3. A Comissão, ou o Alto Representante da União para os Negócios } \\
\text { Estrangeiros e a Política de Segurança nos casos em que o acordo projetado } \\
\text { incida exclusiva ou principalmente sobre a política externa e de segurança } \\
\text { comum, apresenta recomendações ao Conselho, que adota uma decisão que } \\
\text { autoriza a abertura das negociações e que designa, em função da matéria do } \\
\text { acordo projetado, o negociador ou o chefe da equipe de negociação da União. } \\
\text {... } \\
\text { 6. O Conselho, sob proposta do negociador, adota uma decisão de celebração } \\
\text { do acordo. } \\
\text { Exceto nos casos em que o acordo incida exclusivamente sobre a política externa } \\
\text { e de segurança comum, o Conselho adota a decisão de celebração do acordo: } \\
\text {... }\end{array}$ \\
\hline Art. 275 & $\begin{array}{l}\text { O Tribunal de Justiça da União Europeia não dispõe de competência no que diz } \\
\text { respeito às disposiçóes relativas à política externa e de segurança comum, nem } \\
\text { no que diz respeito aos actos adoptados com base nessas disposiçôes. }\end{array}$ \\
\hline
\end{tabular}




\begin{tabular}{|c|c|}
\hline Art. 329 & $\begin{array}{l}\text { 1. Os Estados-Membros que pretendam instituir entre si uma cooperação reforçada } \\
\text { num dos domínios referidos nos Tratados, com exceção dos domínios de competência } \\
\text { exclusiva e da política externa e de segurança comum, devem dirigir um pedido } \\
\text { nesse sentido à Comissão, especificando o âmbito de aplicação e os objetivos } \\
\text { prosseguidos pela cooperação reforçada prevista. A Comissão pode apresentar } \\
\text { ao Conselho uma proposta para o efeito. Caso não apresente uma proposta, a } \\
\text { Comissão informa os referidos Estados-Membros das razões que a motivaram. } \\
\text { A autorização para dar início à cooperação reforçada a que se refere o primeiro } \\
\text { parágrafo é concedida pelo Conselho, sob proposta da Comissão e após aprovação do } \\
\text { Parlamento Europeu. } \\
\text { 2. Os Estados-Membros que pretendam instituir entre si uma cooperação reforçada } \\
\text { no âmbito da politica externa e de segurança comum devem dirigir um pedido nesse } \\
\text { sentido ao Conselho. Esse pedido é transmitido ao Alto Representante da União } \\
\text { para os Negócios Estrangeiros e a Política de Segurança, que emite parecer } \\
\text { sobre a coerência da cooperação reforçada prevista com a política externa e } \\
\text { de segurança comum da União, bem como à Comissão, que emite parecer, } \\
\text { nomeadamente sobre a coerência da cooperação reforçada prevista com as outras } \\
\text { políticas da União. O pedido é igualmente transmitido ao Parlamento Europeu, } \\
\text { para informação. } \\
\text { A autorização para dar início à cooperação reforçada é concedida por } \\
\text { decisão do Conselho, deliberando por unanimidade. }\end{array}$ \\
\hline Art. 352 & $\begin{array}{l}\text { 1. Se uma ação da União for considerada necessária, no quadro das políticas } \\
\text { definidas pelos Tratados, para atingir um dos objetivos estabelecidos pelos } \\
\text { Tratados, sem que estes tenham previsto os poderes de ação necessários para o } \\
\text { efeito, o Conselho, deliberando por unanimidade, sob proposta da Comissão } \\
\text { e após aprovação do Parlamento Europeu, adotará as disposições adequadas. } \\
\text { Quando as disposiçóes em questão sejam adotadas pelo Conselho de acordo } \\
\text { com um processo legislativo especial, o Conselho delibera igualmente por } \\
\text { unanimidade, sob proposta da Comissão e após aprovação do Parlamento } \\
\text { Europeu. } \\
\text {.. } \\
\text { 4. O presente artigo não pode constituir fundamento para prosseguir objetivos } \\
\text { do âmbito da política externa e de segurança comum e qualquer ato adotado } \\
\text { por força do presente artigo deve respeitar os limites estabelecidos no segundo } \\
\text { parágrafo do artigo } 40 \text { do Tratado da União Europeia. }\end{array}$ \\
\hline Protocolo 10 & $\begin{array}{l}\text { Protocolo relativo à cooperação estruturada permanente estabelecida no artigo } \\
42 \text { do Tratado da União Europeia. } \\
\text { As altas partes contratantes, tendo em conta o n.o } 6 \text { do artigo } 42 \text { e o artigo } 46 \\
\text { do Tratado da União Europeia, } \\
\text { Recordando que a União conduz uma política externa e de segurança comum } \\
\text { baseada na realização de um grau de convergência crescente das açâes dos Estados- } \\
\text { Membros, } \\
\text { Recordando que a política comum de segurança e defesa faz parte integrante da } \\
\text { política externa e de segurança comum; que aquela política garante à União uma }\end{array}$ \\
\hline
\end{tabular}




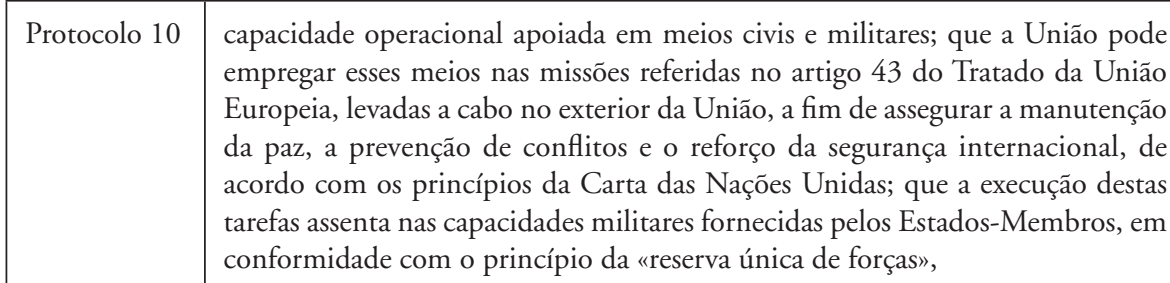

Recordando que a política comum de segurança e defesa da União não afeta o caráter específico da política de segurança e defesa de determinados Estados-Membros,

Recordando que a política comum de segurança e defesa da União respeita as obrigações decorrentes do Tratado do Atlântico Norte para os Estados-Membros que consideram que a sua defesa comum se realiza no quadro da Organização do Tratado do Atlântico Norte, a qual continua a ser o fundamento da defesa coletiva dos seus membros, e é compatível com a política comum de segurança e defesa adotada nesse quadro,

Convictas de que um papel mais assertivo da União em matéria de segurança e de defesa contribuirá para a vitalidade de uma Aliança Atlântica renovada, em conformidade com os acordos de "Berlim Mais",

Determinadas a fazer com que a União seja capaz de assumir plenamente as responsabilidades que the incumbem no âmbito da comunidade internacional,

Reconhecendo que a Organização das Nações Unidas pode solicitar a assistência da União para levar a cabo, em situações de urgência, missões empreendidas ao abrigo dos Capítulos VI e VII da Carta das Naçōes Unidas,

Reconhecendo que o reforço da política de segurança e defesa exigirá esforços dos Estados-Membros no dominio das capacidades,

Conscientes de que a passagem para uma nova fase no desenvolvimento da política europeia de segurança e defesa implicará esforços resolutos por parte dos Estados-Membros que a tal estejam dispostos,

Recordando a importância de que o Alto Representante da Uniāo para os Negócios Estrangeiros e a Politica de Segurança seja plenamente associado aos trabalhos da cooperação estruturada permanente,

Acordaram nas disposições seguintes, que vêm anexas ao Tratado da União Europeia e ao Tratado sobre o Funcionamento da União Europeia:

Artigo $1^{\circ}$

A cooperação estruturada permanente prevista no n.o 6 do artigo 42 do Tratado da União Europeia está aberta a qualquer Estado-Membro que se comprometa, desde a data de entrada em vigor do Tratado de Lisboa, a:

a) Proceder de forma mais intensiva ao desenvolvimento das suas capacidades de defesa, através do desenvolvimento dos respectivos contributos nacionais e, se for caso disso, da participação em forças multinacionais, nos principais programas europeus de equipamento e na atividade da agência no domínio do desenvolvimento das capacidades de defesa, da investigação, da aquisição e do armamento (adiante designada "Agência Europeia de Defesa»); 


\begin{abstract}
Protocolo 10 b) Ser capaz de fornecer, o mais tardar em 2010, quer a título nacional, quer enquanto elemento de grupos multinacionais de forças, unidades de combate especificamente treinadas para as missóes programadas, configuradas em termos táticos como um agrupamento táctico, com os respectivos elementos de apoio, incluindo o transporte e a logística, que estejam em condições de levar a cabo as missóes a que se refere o artigo 43 do Tratado da União Europeia, num prazo de $\mathbf{5}$ a $\mathbf{3 0}$ dias, designadamente para responder a pedidos da Organização das Nações Unidas, e que possam estar operacionais por um período inicial de 30 dias, prorrogável até 120 dias, no mínimo.
\end{abstract}

Artigo $2^{\circ}$

A fim de alcançar os objetivos referidos no artigo 1.o, os Estados-Membros que participem na cooperação estruturada permanente comprometem-se a:

a) Cooperar, desde a entrada em vigor do Tratado de Lisboa, no sentido de alcançar objetivos acordados relativamente ao nível das despesas de investimento em matéria de equipamentos de defesa, e a rever regularmente esses objetivos, em função do ambiente de segurança e das responsabilidades internacionais da União;

b) Aproximar, na medida do possível, os seus instrumentos de defesa, harmonizando, nomeadamente, a identificação das necessidades militares, colocando em comum e, se for caso disso, especializando os seus meios e capacidades de defesa, e incentivando a cooperação nos domínios da formação e da logística;

c) Tomar medidas concretas para reforçar a disponibilidade, a interoperabilidade, a flexibilidade e a capacidade de colocação das suas forças no terreno, identificando, designadamente, objetivos comuns em matéria de projeção de forças, o que poderá passar por uma reapreciação dos respectivos processos de decisão nacionais;

d) Cooperar no sentido de garantir que os Estados-Membros participantes tomem as medidas necessárias para colmatar, designadamente através de abordagens multinacionais e sem prejuízo dos compromissos que os vinculam no âmbito da Organização do Tratado do Atlântico Norte, as lacunas constatadas no âmbito do «Mecanismo de Desenvolvimento de Capacidades»;

e) Participar, se for caso disso, no desenvolvimento de programas comuns ou europeus de grandes equipamentos, no âmbito da Agência Europeia de Defesa.

Artigo $3^{\circ}$

A Agência Europeia de Defesa contribui para a avaliação regular dos contributos dos Estados-Membros participantes em matéria de capacidades, em particular dos contributos dados segundo os critérios a definir, entre outros, com base no artigo $2^{\circ}$, apresentando um relatório sobre o assunto pelo menos uma vez por ano. A avaliação pode servir de base às recomendações e às decisóes do Conselho adotadas nos termos do artigo 46 do Tratado da União Europeia. 


\begin{tabular}{|c|c|}
\hline Declarações & 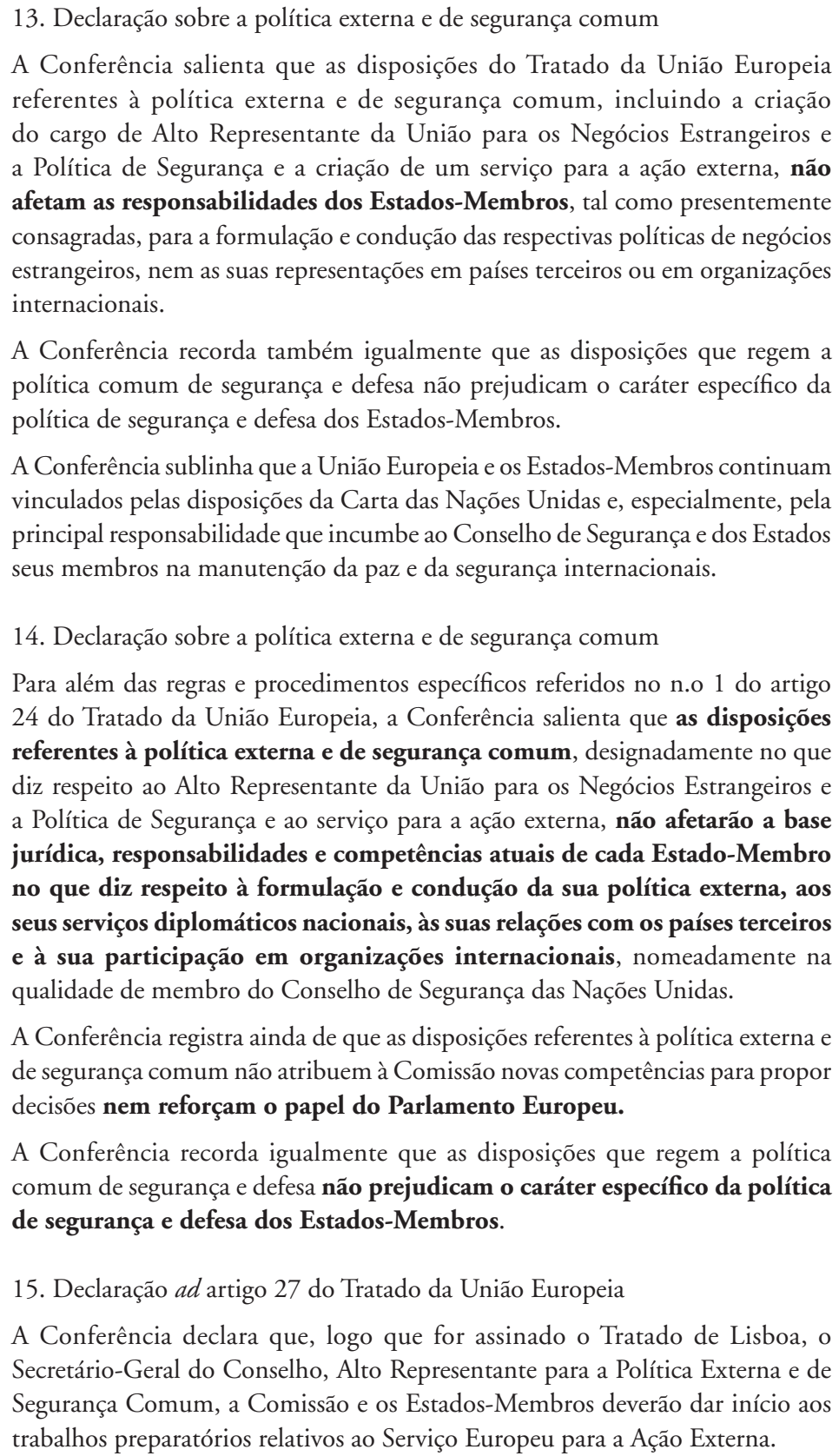 \\
\hline
\end{tabular}

Tem-se na comemoração dos 50 anos do Tratado do Eliseu uma nova fase na parceria franco-alemã e na evolução da União Europeia. Em uma constelação de 27 sócios, o clube europeu continua à busca de estabelecer padróes de 
elaboração, implantação e aprofundamento de políticas comuns que vão além dos campos tradicionais da economia, da aduana e do comércio. O bilateralismo complementar entre Paris e Berlim firmou um entendimento baseado em uma experiência globalmente bem-sucedida. A expectativa de formação de outros possíveis bilateralismos no seio da União Europeia, em subsistemas de cooperação setorial, é um fruto direto dessa experiência. Falta-lhe ainda a efetivação, embora esboços estejam a se delinear. No plano da política externa, as circunstâncias do mundo contemporâneo ainda não permitiram ir além, concretamente, das questôes humanitárias (para as intervenções atuais) e da pacificação nos Bálcãs (uma ameaça anteporta no final dos anos 1990 e nos anos 2000). Os tratados refletem essa ambiguidade: uma posição de destaque para a política externa e de segurança comum (no início do tratado) e uma superposição institucional, malgrado a posição de relevo atribuída ao Alto Representante, como vice-presidente nato da Comissão (Art. 18, \$4, do TUE). É de se imaginar que somente a prática dirá, ao longo da proverbial perseverança europeia, como essa equação se resolverá.

Recebido em 27 de setembro de 2012 Aprovado em 29 de novembro de 2012

\section{Resumo}

Em 2013 o Tratado do Eliseu, de amizade e cooperação entre França e Alemanha completa 50 anos. O modelo de bilateralismo complementar por ele estabelecido instituiu um modelo de cooperação bem sucedido, de cujas características beneficiou-se tanto a dupla francoalemã quanto o itinerário mesmo da União Europeia. A política externa de Paris e Berlim, tornada política interna à Europa, inspira a arquitetura da política externa e de segurança comum, cujo desenvolvimento somente começou com o Tratado de Lisboa, de 2009, cujos entraves operacionais subsistem. O texto dos tratados ecoa a parceria franco-alemã e registra as superposições institucionais remanescentes.

Palavras-chaves: cooperação franco-alemã; política externa e de segurança comum; Tratado do Eliseu; União Europeia.

\section{Abstract}

In 2013 the Elysée Treaty, on friendship and cooperation between France and Germany completes 50 years. Its model of a complementary bilateralism establishes a successful cooperation model, the characteristics of which benefited both the Franco-German couple as the itinerary of the European Union itself. The foreign policy of Paris and Berlin made domestic politics in Europe, inspires the architecture of the common foreign and security policy, whose development began only with the Treaty of Lisbon in 2009, and whose operational barriers remain. The text of treaties echoes the Franco-German partnership and records the remaining institutional overlays.

Keywords: Franco-German cooperation; common foreign and security policy; Elysée Treaty; European Union. 